\title{
Diversity of plant communities with Carex flava agg. in Poland and their relationship with soil properties
}

\author{
Helena Więclaw (D) Marek Podlasiński
}

Received: 2 January 2020 /Revised: 21 June 2020 / Accepted: 12 September 2020 / Published online: 6 November 2020

(C) The Author(s) 2020

\begin{abstract}
The Carex flava aggregate belongs to one of the most taxonomically difficult groups of sedges which colonize diverse habitats, from organic to sandy, from acidic to alkaline, usually humid and moist. The study included 129 vegetation plots and ten soil variables (organic matter, phosphorus, potassium, magnesium, calcium, carbonates, carbon, nitrogen, $\mathrm{pH}$, and the ratio between organic carbon and nitrogen). The main aim was to determine the relationships between the various plant communities C. flava agg. occur in and their soil properties. With the aid of the two-way indicator species analysis and cluster analysis, we delimited nine vegetation types from the Scheuchzerio palustris-Caricetea fuscae, Littorelletea uniflorae, MolinioArrhenatheretea and Alnetea glutinosae classes differing in their response to soil properties. The CCA revealed $\mathrm{pH}, \mathrm{N}, \mathrm{K}, \mathrm{C}, \mathrm{CaCO}_{3}, \mathrm{P}$ and $\mathrm{Ca}$ to be statistically significant, and to account for $11.55 \%$ of the total variance in species composition. The largest differences, both in terms of species composition and in soil condi-
\end{abstract}

Supplementary Information The online version of this article (https://doi.org/10.1007/s12224-020-09375-3) contains

supplementary material, which is available to authorized users.

H. Więcław $(\bowtie)$

Institute of Marine and Environmental Sciences, University of Szczecin, Adama Mickiewicza 18, 70-383 Szczecin, Poland e-mail: helena.wieclaw@usz.edu.pl

M. Podlasiński

Department of Environmental Management, West Pomeranian University of Technology, Słowackiego 17, 71-434 Szczecin, Poland tions, were revealed between communities with C. lepidocarpa and C. demissa. Carex lepidocarpa occurred in calcareous and extremely rich fens (Caricion davallianae) whereas $C$. demissa was found to occur in poor and moderately rich fens (Sphagno-Caricion canescentis, Caricion canescenti-nigrae). Carex flava grew mostly in calcareous, rich fens and wet grasslands (Caricion davallianae, Calthion palustris). Carex viridula was found in both calcareous, extremely and moderately rich fens and wet grasslands, and in nutrientpoor habitats such as dunes and sandy lake shores. The ecological niche of $C$. viridula is very wide and this species showed no affinity to any specific syntaxon.

Keywords sedges $\cdot$ soil properties $\cdot$ vegetation composition $\cdot$ wetlands

\section{Introduction}

The Carex flava complex belongs to one of the most taxonomically difficult groups because of a lack of clear morphological discontinuities (e.g. Havličková 1982; Crins and Ball 1989a,b; Pykälä and Toivonen 1994; Jiménez-Mejías et al. 2012) and the presence of numerous hybrids (Schmid 1982; Więcław and Koopman 2013; Więcław and Wilhelm 2014). The Carex flava complex in Europe is considered consisting of six species (Więcław 2017). These taxa are usually small in size and have short rhizomes; they usually have a solitary subcylindrical male spike on top of the inflorescence, above globose to oblong female spikes with more 
or less inflated, ovoid-ellipsoid utricles with a distinct bifid beak (Chater 1980). In Poland, the C. flava group contains four taxa: C. flava, C. lepidocarpa subsp. lepidocarpa, C. demissa subsp. demissa and C. viridula var. viridula (Więcław 2014a). Carex viridula var. pulchella, identified earlier in Poland by Zając (1968), is most likely part of the continuum of variation within var. viridula resulting from effects of local habitat conditions (Więcław 2017). The most important for the identification of taxa of the C. flava group are generative characters, particularly dimensions of the utricle and beak, from the longest in C. flava via C. lepidocarpa and C. demissa to the shortest in C. viridula, as well as the beak length/utricle length ratio, the diminishing order of which starts with C. flava to proceed via $C$. demissa, C. lepidocarpa to C. viridula (e.g. Pykälä and Toivonen 1994; Więcław 2014a). In addition, two or more taxa of the C. flava aggregate may share a site; such mixed populations frequently contain hybrids (e.g. Więcław and Wilhelm 2014; Schmidt et al. 2018).

Carex flava and C. viridula are frequent in Poland, whereas C. lepidocarpa is relatively rare. Carex demissa is found scattered across the country, mostly in the south (Więcław 2014b). The relatively most common hybrids are $C$. ×alsatica $[C$. demissa $\times$ C. flava] and C. $\times$ subviridula [C. flava $\times$ C. viridula]. In Poland, the taxa from the $C$. flava group usually grow in fens, wet meadows, along lake, sea and pond shores, along ditches, roadsides, in pastures, along streams and rivers, and less frequently in forests (Więcław 2014b). They colonize diverse substrates, from organic to sandy and from acidic to alkaline, usually humid and moist (e.g. Davies 1956; Schmid 1984; Crins and Ball 1989b). Sedges of the C. flava complex can grow in different plant assemblages, usually representing the classes Scheuchzerio palustrisCaricetea fuscae, Isoëto-Nanojuncetea, Littorelletea uniflorae, Molinio-Arrhenatheretea, PhragmitoMagnocaricetea and Alnetea glutinosae (e.g. Hájková et al. 2010; Hájek and Hájková 2011; Šumberová 2011; Šumberová and Hrivnak 2013; Vončina 2017). For example, C. flava and C. lepidocarpa are regarded as species typical of communities included in the Caricion davallianae, for example Caricetum paniceolepidocarpae (Kwiatkowski 1999), Carici flavaeBlysmetum compressi, Carici flavae-Eriophoretum latifolii (Zamfirescu and Zamfirescu 2006), Valeriano simplicifoliae-Caricetum flavae (Pawłowski et al. 1960;
Hájek 1999; Hájek and Hájková 2002; Hájek et al. 2005) and Carici flavae-Cratoneuretum (Hájek et al. 2005). On the other hand, because of the morphological similarity of the sedges and difficulties in their identification, some phytosociological publications treat them as a broadly-defined aggregate; for example, Jarolímek and Šibík (2008) mentioned Carex flava agg. as diagnostic for the class Scheuchzerio palustris-Caricetea fuscae and the alliance Caricion davallianae (see also Hájek 2002; Peterka et al. 2017). Moreover, most phytosociological and ecological studies were focused on C. flava and C. lepidocarpa, and less so on C. demissa and C. viridula (e.g. Hájek 1999, 2002; Hájek and Hájková 2002). In addition, closely related species which are poorly morphologically differentiated can be easily overlooked or the differences observed may be regarded as a manifestation of habitat-dependent variation. Therefore, this study was aimed at identifying types of plant assemblages capable of supporting species of the C. flava complex and at determining relationships between soil properties and species composition and diversity of vegetation with $C$. flava agg.

The results presented are part of a comprehensive study on the taxa of the C. flava complex in Poland, with a particular reference to inter- and intra-specific differentiation, taxonomy and hybridisation within the group (Więcław and Podlasiński 2013; Więcław and Koopman 2013; Więcław and Wilhelm 2014; Więcław 2014a,b, Więcław 2017).

\section{Material and methods}

Field sampling

Field data were collected in 2012-2014 in Poland from various habitats, for example from upland and lowland, coastal and inland, from calcareous, extremely and moderate-rich fens and wet grasslands to poor habitats such as dunes and sandy lake shores (Fig. 1; Online Resource 1). A total of 129 plots were sampled in patches with the presence of species from C. flava agg., specifically 16 with $C$. demissa subsp. demissa, 57 with C. flava s.str., 19 with C. lepidocarpa subsp. lepidocarpa and 37 with C. viridula var. viridula. The sedges were identified using the keys of Pykälä and Toivonen (1994) and Więcław (2014a).

The area of vegetation plots was in the range of 10 $30 \mathrm{~m}^{2}$. The species cover in each plot was estimated 


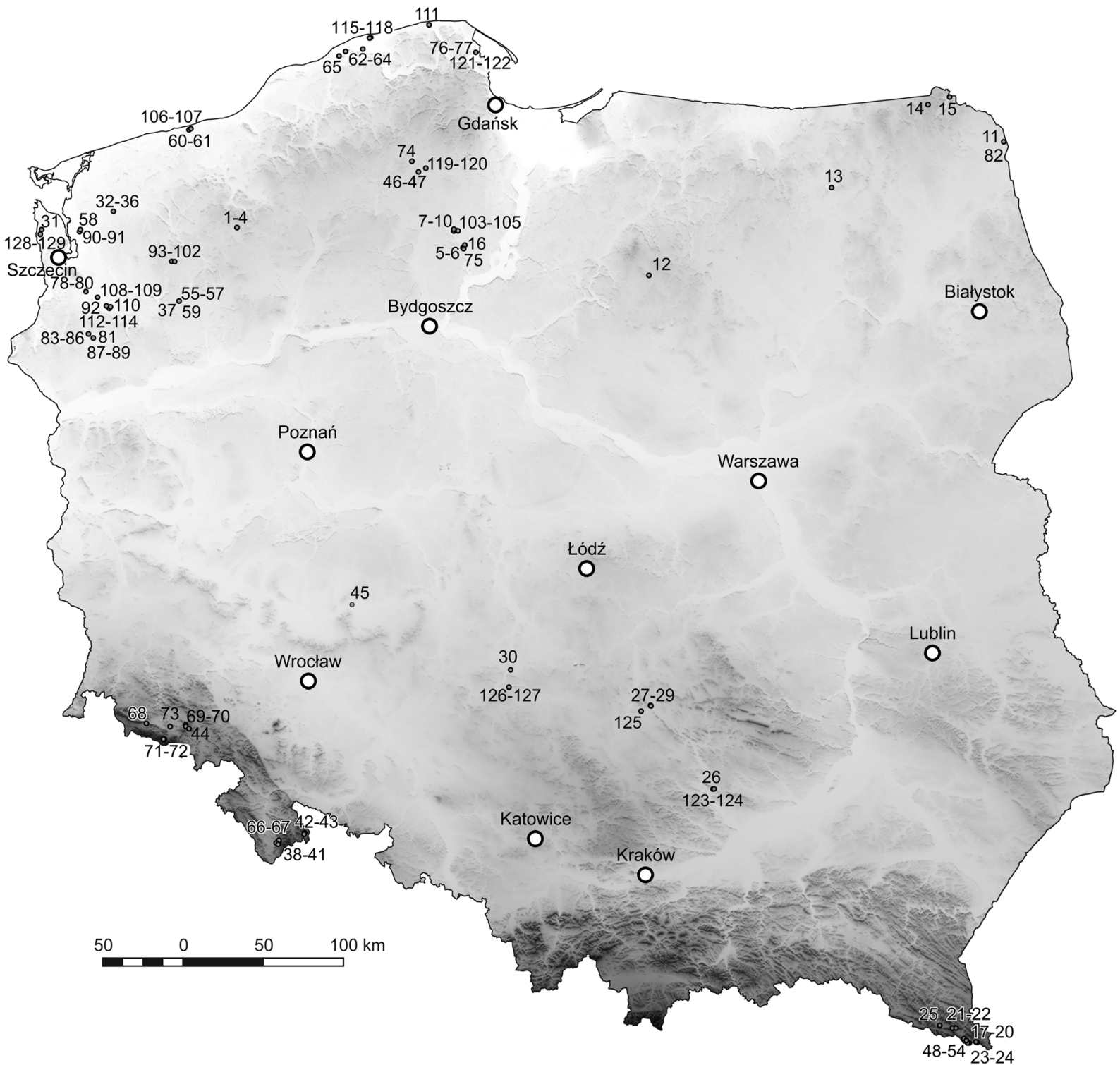

Fig. 1 Locations of Carex flava agg. sampling sites. 1, 2, 3, 4 ..number of relevé; relevés 1, 3, 5-15, 21, 26, 28-36, 38-47, 55-58 - samples with $C$. flava from fens and wet grasslands without Valeriana dioica subsp. simplicifolia (cluster VII); relevés 2, 4, 16, 27, 37 - samples with C. flava from Alnus forest (cluster VIII); relevés 17-20, 22-25, 48-51, 53, 54- samples with C. flava from fens and wet grasslands with Valeriana dioica subsp. simplicifolia from the Bieszczady Mts (cluster VI); relevés 52, 66, 68-72 samples with $C$. demissa from poor acidic fens (cluster $\mathrm{Va}$ );

using a nine-grade scale (van der Maarel 1979). All the vascular plant and bryophyte species were recorded and their respective cover-abundances were coded as follows: 1 (one or a few individuals); 2 (rare and less than $1 \%$ cover); 3 (less than 5\% cover; several specimens); 4 relevés $59,60-65,67,73$ - samples with $C$. demissa from moderate-rich fens and fen grasslands (cluster $\mathrm{Vb}$ ); relevés 74-92 samples with C. lepidocarpa (cluster I); relevés 106-109 and 119129 - samples with $C$. viridula from fens and wet grasslands (cluster II); relevés 93-105 - samples with $C$. viridula from sandy lake shores (cluster IIIa), relevés 110, 112-114 - samples with C. viridula from sites near a chalk mine (cluster IIIb), relevés 111, 115-118 - samples with C. viridula from dunes (cluster IV).

(less than 5\% cover; abundant); 5 (5-12.5\% cover); 6 (12.5-25\% cover); 7 (25-50\% cover); 8 (50-75\% cover); 9 (75-100\% cover). At each plot, three soil samples were collected with an Egner's soil sampler from the plant root zone $(0-25 \mathrm{~cm})$. The three samples were 
combined to form a single soil sample, representing a given plot and used for chemical analyses.

Soil analysis

Soil samples were dried at room temperature, and then rubbed through a sieve to remove fractions larger than 1 $\mathrm{mm}$. The following properties were determined in the thus-prepared material: organic matter content (as loss on ignition at $550^{\circ} \mathrm{C}$ ), $\mathrm{pH}$ (potentiometrically in $1 \mathrm{M}$ $\mathrm{KCl}$ ), contents of assimilable nutrients (phosphorus $\mathrm{P}$, potassium $\mathrm{K}$, magnesium $\mathrm{Mg}$ and calcium $\mathrm{Ca}$, using the American Society of Agronomy method; Sparks et al. 1996), carbonates (Scheibler's method; Tatzber et al. 2007) and total carbon $C$ and nitrogen N (CHNS analyser, Costech Analytical Technologies Inc.; Sparks et al. 1996). The latter assay provides data for calculating the $\mathrm{C} / \mathrm{N}$ ratio. The ratio between organic carbon and nitrogen $(\mathrm{C} / \mathrm{N})$ is one of the indicators of soil fertility. The lower the ratio, the more fertile the soil.

\section{Data processing}

Two multivariate statistical techniques were used to analyse the vegetation data: the two-way indicator species analysis (TWINSPAN package, v. 2.3; Hill and Šmilauer 2005) and the cluster analysis (MVSP package, v. 3.1; Kovach 1985-1999). Each of these approaches provides a somewhat different view on the structure of the data, and when employed together they can be used to better understand the diversification of the vegetation. Clusters resulting from divisions (TWINSPAN) with eigenvalues greater than 0.3 are treated as the final clusters which, however, do not necessarily constitute communities. The cluster classification (MVSP) was performed using the minimum variance, based on the squared Euclidean distance.

The statistical significance of differences between empirical distributions of the data analysed and the theoretical normal distribution was examined using the Shapiro-Wilk test. Since distributions of most data sets deviated from normality, the non-parametric U MannWhitney test, Kruskal-Wallis test and Dunn's multiple comparisons test were used to examine whether differences between sites of $C$. flava agg. species and between relevés (Shannon diversity index, the evenness and number of species) were significant. Calculations were performed using the software package Statistica v. 13.1 for Windows (StatSoft, Inc. 2013). The Shannon diversity index and the evenness were calculated for each relevé using the MVSP package (Kovach 19851999).

Relationships between vegetation plots and environmental factors were determined using the software package CANOCO v. 4.51 (ter Braak and Šmilauer 2002). Vegetation distribution patterns in relation to environmental variables were explored using canonical correspondence analysis (CCA), after detrended correspondence analysis (DCA) detected a unimodal structure of the species data (the gradient length represented by the first ordination axis was greater than $3 S D$ ). The Monte Carlo permutation test was further applied to test for statistical significance of environmental variables.

Nomenclature

The nomenclature of vascular plants, Carex taxa and mosses follows World Flora Online (WFO 2020), Koopman (2015) and Ochyra et al. (2003), respectively. The phytosociological units are in compliance with the syntaxonomic nomenclature of the vegetation of Europe (Mucina et al. 2016). Assignment to phytosociological units below the class level follows Matuszkiewicz (2018) and Dierßen (2001). The fen terminology is in accordance with Hajek et al. (2006). Specimens collected in the field have been deposited in the Herbarium Stetinensis (SZUB).

\section{Results}

Floristic composition and diversity of plant communities with taxa representing Carex flava agg

The TWINSPAN resulted in eight final clusters (I-VIII; see Online Resource 2 and 3). The first division of the dataset separated plots with C. lepidocarpa and C. viridula from $C$. flava and $C$. demissa. The division was based on indicators: $C$. viridula with a coverage of 3 or more, and $C$. lepidocarpa with a coverage of 2 or more. All the relevés with $C$. lepidocarpa coverage of more than 2 were assigned to a single vegetation unit (cluster I) whereas the relevés with $C$. viridula coverage of 3 and more were divided into three groups (Online Resource 2). The division of the three groups was based on indicators: Bryum pseudotriquetrum with a coverage of 2 and more (cluster III) and Pohlia nutans with a coverage of 1 and more (cluster IV). Cluster II 
contained relevés dominated by species of the classes Scheuchzerio palustris-Caricetea fuscae (e.g. Carex nigra, C. panicea, Campylium stellatum) and MolinioArrhenatheretea (e.g. Molinia caerulea, Lythrum salicaria, Deschampsia cespitosa). All the relevés with C. demissa were assigned to a single vegetation unit (cluster V), with a $C$. demissa coverage of 3 and more (Online Resource 3), as an indicator. The relevés with C. flava were divided into three clusters. Clusters VI and VIII were identified by the presence of Valeriana dioica subsp. simplicifolia and Alnus glutinosa, respectively. Cluster VI covers relevés taken exclusively in the mountainous area in south-eastern Poland whereas cluster VII groups relevés from both lowlands throughout the country and mountains and uplands, mainly in the SouthWest of Poland. These relevés are distinct by the absence of Valeriana dioica subsp. simplicifolia, while $V$. dioica s.str. is frequent (Online Resource 3).

The MVSP resulted in the division of the entire dataset into two main groups; the first one contained relevés with $C$. lepidocarpa and $C$. viridula, while relevés in the other group contained relevés with C. flava and C. demissa (Fig.2a). Further analyses of the main groups showed that some relevés with C. viridula were included in the group with C. lepidocarpa, while some of the relevés with $C$. flava were assigned to the group with $C$. demissa (Fig. 2b, c). The MVSP demonstrated a separate nature of relevés with $C$. viridula from dunes (cluster IV versus clusters III and II), shores of water bodies and the vicinity of a chalk mine (cluster IIIa versus cluster IIIb), as well as relevés with $C$. demissa (cluster Va versus $\mathrm{Vb}$ ) and those with $C$. flava (cluster VI versus cluster VII), see Fig. 2b,c; Online Resource 2 and 3).

Relevés with $C$. lepidocarpa (cluster I) were similar in terms of their floristic composition and proportions of species (Online Resource 2). Such a species composition is characteristic of the association Caricetum paniceo-lepidocarpae. It is dominated by diagnostic species such as $C$. lepidocarpa and $C$. panicea; there are also calciphilous vascular plants (e.g. Carex flacca, Epipactis palustris and Parnassia palustris) and mosses (e.g. Campylium stellatum and Fissidens adianthoides, see Online Resource 2). The number of species per relevé averaged 22; Shannon's diversity index and evenness averaged 4.22 and 0.96 , respectively (Table 1).

Relevés featuring $C$. viridula, taken along lake shores (cluster IIIa), were distinct by the presence of species representing the classes Montio-Cardaminetea, Potamogetonetea, Littorelletea uniflorae and IsoëtoNanojuncetea. Samples from the vicinity of the chalk mine (cluster IIIb) showed a low contribution of species representing the classes listed above (only Cardamine amara, Bryum pseudotriquetrum and Drepanocladus polycarpos were present) whereas species belonging to the Phragmito-Magnocaricetea (e.g. Cladium mariscus, Carex disticha, Schoenoplectus tabernaemontani) and Molinio-Arrhenatheretea (e.g. Juncus subnodulosus, Linum catharticum) occurred. Some relevés contained the calciphilous Samolus valerandi and Campylium stellatum (Online Resource 2). Plots dominated by C. viridula, occurring on exposed sandy shores (cluster IIIa), were classified as the assemblage RanunculoJuncetum bulbosi, variant with $C$. viridula. The assemblage was made up of several Juncus species (J. articulatus, J. bufonius, J. bulbosus) and a number of fen species such as Agrostis canina and Hydrocotyle vulgaris (Online Resource 2).

Patches featuring C. viridula observed in depressions between dunes (cluster IV) were characterized by the presence of species representing the classes Oxycocco-Sphagnetea (e.g. Drosera rotundifolia, Vaccinium oxycoccus, Aulacomnium palustre) and Nardetea strictae (Calluna vulgaris, Pohlia nutans, Empetrum nigrum), and the order Scheuchzerietalia palustris (Drosera anglica, Lycopodiella inundata, Sphagnum teres). Relevés with $C$. viridula from wet grasslands and fens (cluster II) showed a presence of species from the class Molinio-Arrhenatheretea (e.g. Lysimachia vulgaris, Ranunculus acris, Lotus pedunculatus) and the order Caricetalia fuscae (e.g. Hydrocotyle vulgaris, Carex nigra, Veronica scutellata, see Online Resource 2). The fen and wet grassland relevés differed significantly from those of dunes in terms of the Shannon diversity index and the species richness $(P=0.0193$ and $P=0.0091$, respectively) as well as from those from lake shores $(P=$ 0.0048 and $P=0.0040$, respectively). The species richness in fen and wet grassland averaged 21 per relevé (Shannon index of 4.12) and 11 (Shannon index of 3.29) and 14 species (Shannon index of $3.56)$ in dune and lakeshore relevés, respectively.

The relevés with $C$. demissa were divided into two groups (Va and Vb; see Fig. 2c and Online Resource 3). Those included into cluster Va were distinct by the presence of species representing the classes Nardetea strictae (e.g. Nardus stricta, Potentilla erecta) and 

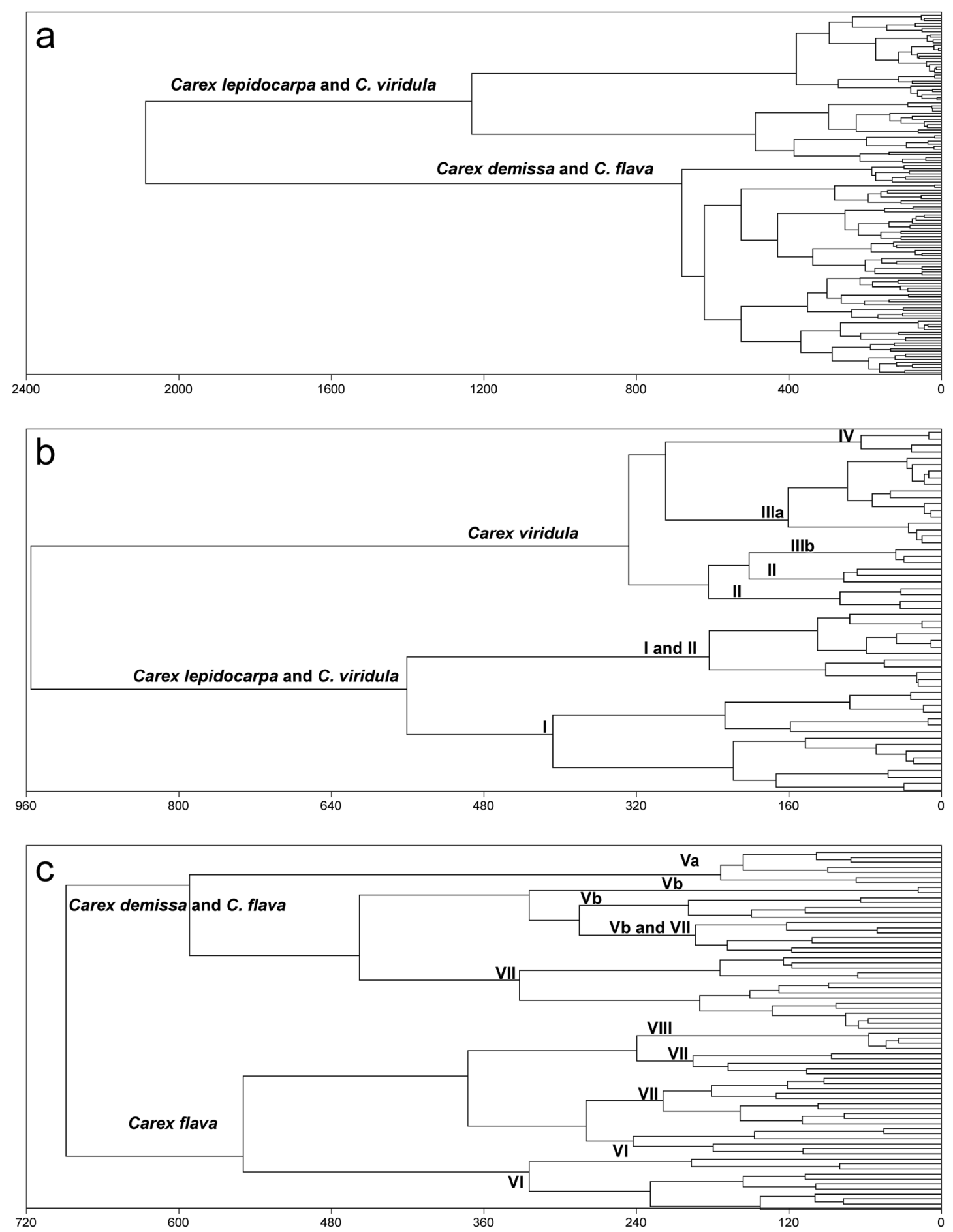

Fig. 2 Results of hierarchical cumulative classification using Euclidean distance-based minimum variance techniques. a - Results for the entire dataset; $\mathrm{b}$ - Analysis for plots of C. lepidocarpa (cluster I) and C. viridula (II - samples from fens and wet grasslands, IIIa - sandy lakeshores, IIIb - sites near a chalk mine, and $\mathrm{IV}$ - dunes); $\mathrm{c}$ - Analysis for C. demissa $(\mathrm{Va}$ - samples from poor acidic fen and $\mathrm{Vb}$ - moderate-rich fens and fen grasslands) and C. flava (VI - samples with C. flava from fens and wet grasslands with Valeriana dioica subsp. simplicifolia from Bieszczady Mts, VII - fens and wet grasslands without Valeriana dioica subsp. simplicifolia, and VIII - from Alnus forest). 
Table 1 Diversity of species occurrence in phytocoenoses with Carex flava agg.; results of Kruskal-Wallis test and post hoc Dunn's multiple comparisons test, showing significance of differences in Shannon's index, evenness and number of species. F -
C. flava s.str.; D - C. demissa $; \mathrm{L}-$ C. lepidocarpa $; \mathrm{V}-$ C. viridula; $\times$ - mean; $P$ - statistical significance. The Significance level of $P \leq$ 0.05 is denoted in bold.

\begin{tabular}{|c|c|c|c|c|c|c|c|c|c|c|c|c|}
\hline \multirow{3}{*}{ Shannon's method } & \multicolumn{4}{|l|}{ Species } & \multicolumn{2}{|c|}{ Kruskal-Wallis test } & \multicolumn{6}{|c|}{ Dunn's multiple comparisons test } \\
\hline & \multirow{2}{*}{$\begin{array}{l}\mathrm{D} \\
\times \pm S D\end{array}$} & \multirow{2}{*}{$\begin{array}{l}\mathrm{F} \\
\times \pm S D\end{array}$} & \multirow{2}{*}{$\begin{array}{l}\mathrm{L} \\
\times \pm S D\end{array}$} & \multirow{2}{*}{$\begin{array}{l}\mathrm{V} \\
\times \pm S D\end{array}$} & & & \multirow{2}{*}{$\begin{array}{l}\mathrm{D}-\mathrm{F} \\
P\end{array}$} & \multirow{2}{*}{$\begin{array}{l}\mathrm{D}-\mathrm{L} \\
P\end{array}$} & \multirow{2}{*}{$\begin{array}{l}\mathrm{D}-\mathrm{V} \\
P\end{array}$} & \multirow{2}{*}{$\begin{array}{l}\text { F-L } \\
P\end{array}$} & \multirow{2}{*}{$\begin{array}{l}\mathrm{F}-\mathrm{V} \\
p\end{array}$} & \multirow{2}{*}{$\begin{array}{l}\mathrm{L}-\mathrm{V} \\
p\end{array}$} \\
\hline & & & & & $H$ & $P$ & & & & & & \\
\hline Index & $4.61 \pm 0.39$ & $4.84 \pm 0.31$ & $4.22 \pm 0.59$ & $3.78 \pm 0.52$ & 70.34 & 0.000 & 0.464 & 0.389 & 0.000 & 0.000 & 0.000 & 0.141 \\
\hline Evenness & $0.97 \pm 0.01$ & $0.98 \pm 0.01$ & $0.96 \pm 0.01$ & $0.96 \pm 0.01$ & 52.71 & 0.000 & 1.000 & 0.148 & 0.001 & 0.000 & 0.000 & 0.928 \\
\hline Num.Spec. & $27 \pm 6.43$ & $32 \pm 6.15$ & $22 \pm 7.86$ & $16 \pm 5.74$ & 69.11 & 0.000 & 0.431 & 0.529 & 0.000 & 0.000 & 0.000 & 0.108 \\
\hline
\end{tabular}

Oxycocco-Sphagnetea (Sphagnum fallax, Polytrichum strictum), as well as by a lower contribution of wet grassland species, compared to relevés in cluster $\mathrm{Vb}$ (Online Resource 3). The two groups identified by the MVSP were significantly different in their numbers of species (23 and 31 in clusters $\mathrm{Va}$ and $\mathrm{Vb}$, respectively; Z $=-2.2229 ; P=0.0262)$, the Shannon diversity index (4.35 and 4.80 for clusters $\mathrm{Va}$ and $\mathrm{Vb}$, respectively; $\mathrm{Z}=$ $-2.1170 ; P=0.0343)$ and evenness $(0.97$ and 0.98 for clusters $\mathrm{Va}$ and $\mathrm{Vb}$, respectively; $\mathrm{Z}=-2.4346 ; P=$ 0.0149).

The C. flava relevés proved most species-rich, the Shannon index and the evenness being at their highest as well (Table 1). Relevés acquired in the Bieszczady Mountains (cluster VI) were significantly different from the remaining relevés (clusters VII and VIII) in terms of their Shannon index, evenness, and the number of species ( 5.07 vs 4.77 and $4.75, P=0.0042 ; 0.98$ vs 0.97 and $0.97, P=0.0208$; 38 vs 30 and $30, P=0.0042$, respectively). The Bieszczady Mts support a floristically rich variant of the Valeriano simplicifoliae-Caricetum flavae which featured, fairly frequently, Valeriana dioica subsp. simplicifolia and Eriophorum latifolium, while in other regions the assemblages with $C$. flava featured fairly abundant Valeriana dioica s.str. All the relevés with C. flava showed an abundance of Juncus articulatus and small sedges such as $C$. panicea and C. nigra (Online Resource 3). Moreover, species primarily characteristic of wet grassland associations (e.g. Anthoxanthum odoratum, Briza media, Cirsium palustre, Climacium dendroides, Festuca rubra, Geum rivale, Myosotis scorpioides and Ranunculus acris) were also frequent. Some relevés from cluster VII were dominated by wetland species, for example Blysmus compressus (relevés 15 and 21), Carex hartmanii (40 and 41) and Equisetum palustre (12, 14 and 43, see Online Resource 3.

Distribution of plots and species along environmental gradients

The CCA results indicate that all the variables analysed accounted for $14.36 \%$ of the total variance in the species data (Table 2). The first axis and all the canonical axes were significant as tested by the unrestricted Monte Carlo permutation test (first axis: $P=0.026$; all axes:

Table 2 Summary of CCA of vegetation samples collected at sites with the presence of species from the C. flava complex.

\begin{tabular}{|c|c|c|c|c|}
\hline Axis & $\mathbf{I}$ & II & III & IV \\
\hline Eigenvalues & 0.277 & 0.169 & 0.157 & 0.139 \\
\hline Species-environment correlations & 0.875 & 0.810 & 0.838 & 0.756 \\
\hline Cumulative percentage variance of species data & 3.2 & 5.2 & 7.0 & 8.7 \\
\hline $\begin{array}{l}\text { Cumulative percentage variance } \\
\text { of species-environment relation }\end{array}$ & 22.5 & 36.2 & 49.0 & 60.3 \\
\hline Sum of all eigenvalues/ Total inertia & & & & 8.573 \\
\hline Sum of all canonical eigenvalues & & & & 1.231 \\
\hline Percentage of explained species data variance & & & & 14.36 \\
\hline
\end{tabular}


$P=0.006)$. The results of forward selection in the CCA revealed seven variables $\left(\mathrm{pH}, \mathrm{N}, \mathrm{K}, \mathrm{C}, \mathrm{CaCO}_{3}, \mathrm{P}\right.$ and $\mathrm{Ca})$ to be statistically significant and to account for $11.55 \%$ of the total variance in species composition (Table 3).

In the ordination space (CCA), all the C. lepidocarpa relevés occupy the right-hand part of the diagram and are associated with relatively high $\mathrm{pH}$ values and soil $\mathrm{Ca}, \mathrm{Mg}, \mathrm{CaCO}_{3}, \mathrm{C}$ and $\mathrm{N}$, as well as with a relatively high $\mathrm{C} / \mathrm{N}$ ratio (Fig. 3; Table 4). The C. lepidocarpa habitat differed significantly from habitats of C. demissa, C. flava and C. viridula by being relatively rich in carbonates, calcium and magnesium in the soil, as well as showing a high soil $\mathrm{pH}$ (Table 5).

Relevés of $C$. viridula are scattered in the ordination space; however, most samples collected from dunes (cluster IV) and lake shores (cluster IIIa) are positioned in the left-hand side of the diagram and are associated with relatively low values of most soil parameters studied (Fig. 3; see also Table 5). The relevés taken from fens and wet grasslands (cluster II) are concentrated mainly in the central part of the diagram whereas samples collected from sites near the chalk mine (cluster $\mathrm{IIIb}$ ) are placed in the right-hand part of the diagram together with samples of $C$. lepidocarpa. Statistically significant differences, primarily concerning $\mathrm{pH}$ and soil contents of organic matter, $\mathrm{C}, \mathrm{N}, \mathrm{Mg}, \mathrm{Ca}$ and $\mathrm{CaCO}_{3}$ were detected between relevés from dunes (IV) and fens and wet grasslands (II), as well as between dunes (IV) and sites near the chalk mine (IIIb), see Fig. 4a-h.

All the relevés with $C$. demissa occupy the left-hand part of the CCA diagram and are associated with

Table 3 Forward selection results with the test of variable significance for vegetation samples collected at sites with the presence of species from the C. flava complex. $\mathrm{C}$ - carbon concentration; $\mathrm{N}$ - nitrogen concentration; $\mathrm{C} / \mathrm{N}$ - ratio between organic carbon and

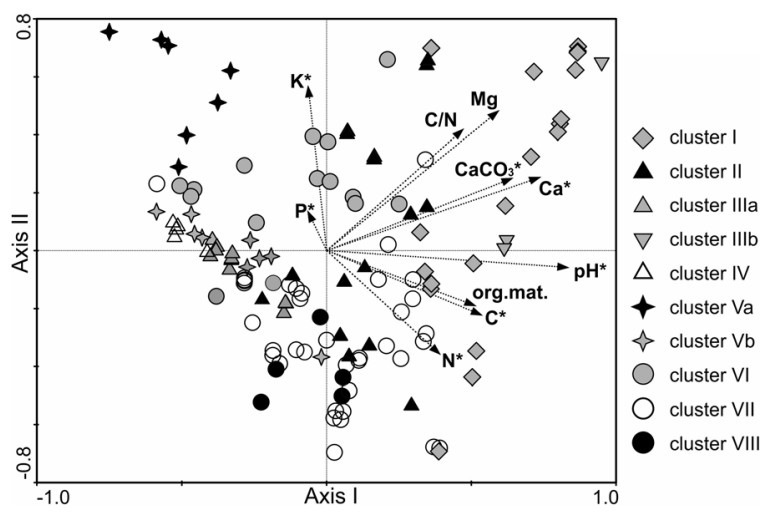

Fig. 3 Ordination diagram of vegetation samples and environmental variables along the first two CCA axes; cluster I - samples with $C$. lepidocarpa; cluster II - samples with $C$. viridula from fens and wet grasslands; cluster IIIa - samples with $C$. viridula from sandy lake shores; cluster IIIb - samples with $C$. viridula from sites near a chalk mine; cluster IV - samples with $C$. viridula from dunes; cluster $\mathrm{Va}$ - samples with $C$. demissa from poor acidic fens; cluster $\mathrm{Vb}$ - samples with $C$. demissa from moderate-rich fens and fen grasslands; cluster VI - samples with C. flava from fens and wet grasslands with Valeriana dioica subsp. simplicifolia from the Bieszczady Mts; cluster VII - samples with C. flava from fens and wet grasslands without Valeriana dioica subsp. simplicifolia; cluster VIII - samples with C. flava from Alnus forest; * - statistically significant variables, significance level $P$ $\leq 0.05$. For abbreviations of soil properties, see Table 3 .

relatively low values of most soil parameters studied (Fig. 3). The upper part of the diagram contains the relevés from poor acidic fens (cluster $\mathrm{Va}$ ), while the relevés from moderate-rich fens (cluster $\mathrm{Vb}$ ) are grouped in the central part. Significant differences between them concerned $\mathrm{pH}$ and the soil Ca content (Fig. $4 d, g)$.

nitrogen concentration; org. mat. - organic matter content; $\mathrm{pH}-$ soil $\mathrm{pH} ; \mathrm{Ca}$ - calcium concentration; $\mathrm{CaCO}_{3}$ - carbonates concentration; $\mathrm{Mg}$ - magnesium concentration; $\mathrm{P}$ - phosphorus concentration; $\mathrm{K}$ - potassium concentration; * significance level $P \leq 0.05$.

\begin{tabular}{|c|c|c|c|c|}
\hline Variables & LambdaA & $\begin{array}{l}\text { Explained data variance } \\
{[\%]}\end{array}$ & $F$ & $P$ \\
\hline $\mathrm{pH}^{*}$ & 0.23 & 2.68 & 3.60 & 0.002 \\
\hline $\mathrm{N}[\%]^{*}$ & 0.15 & 1.75 & 2.45 & 0.002 \\
\hline $\mathrm{K}[\mathrm{mg} / \mathrm{kg}]^{*}$ & 0.15 & 1.75 & 2.36 & 0.002 \\
\hline $\mathrm{C}[\%]^{*}$ & 0.15 & 1.75 & 2.35 & 0.002 \\
\hline $\mathrm{CaCO}_{3}[\%]^{*}$ & 0.11 & 1.28 & 1.69 & 0.024 \\
\hline $\mathrm{P}[\mathrm{mg} / \mathrm{kg}]^{*}$ & 0.10 & 1.17 & 1.55 & 0.022 \\
\hline $\mathrm{Ca}[\mathrm{mg} / \mathrm{kg}]^{*}$ & 0.10 & 1.17 & 1.54 & 0.028 \\
\hline org.mat. [\%] & 0.09 & 1.05 & 1.54 & 0.080 \\
\hline $\mathrm{C} / \mathrm{N}$ & 0.08 & 0.93 & 1.38 & 0.084 \\
\hline $\mathrm{Mg}[\mathrm{mg} / \mathrm{kg}]$ & 0.07 & 0.82 & 1.18 & 0.202 \\
\hline
\end{tabular}




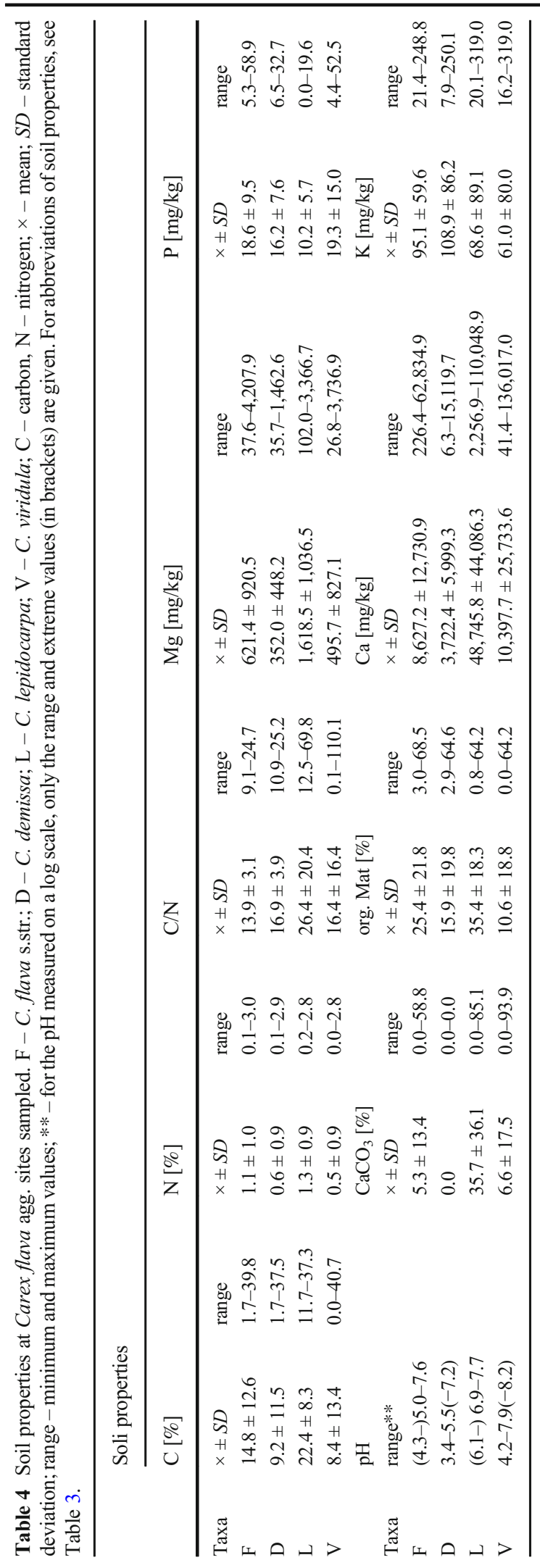

Plots of C. flava are scattered on the CCA diagram; however, relevés from the Bieszczady Mts (cluster VI) are situated in the upper part whereas the remaining relevés from fens and wet grasslands (cluster VII), as well as all the forest relevés (cluster VIII), are grouped in the lower part (Fig. 3). Statistically significant differences between the Bieszczady relevés and the other relevés were revealed for soil organic matter content, as well as for concentrations of carbon, nitrogen, magnesium and potassium (Fig. 4a-c,f,e).

\section{Discussion}

Vegetation types with taxa representing Carex flava agg

We delimited nine vegetation types with taxa included in the Carex flava group that differed in their species composition and response to soil properties.

Carex lepidocarpa is a characteristic species of the assemblage Caricetum paniceo-lepidocarpae from the alliance Caricion davallianae (Kwiatkowski 1999). In Poland C. lepidocarpa grows only in calcareous sites (calcareous, extremely rich and rich fens). Those habitats are severely threatened due mainly to general and wide-scale disturbances in hydrological conditions (Wołejko et al. 2005; Šefferová Stanová et al. 2008; Grootjans et al. 2015). Moreover, C. lepidocarpa is sensitive to changes in hydrology and becomes increasingly rare. It is regarded as threatened in some Central European countries (Pykälä 1994).

Carex flava s.str. is found in calcareous, rich and moderate-rich fens and wet grasslands as well as in alder thickets and woods. In Poland, it grows on soils with a wide $\mathrm{pH}$ range, from (4.3-)5.0 to 7.6. Carex flava is one of the diagnostic species of the Valeriano simplicifoliae-Caricetum flavae, found in mountainous regions, throughout the flysch zone of the Slovak, Polish and Ukrainian Carpathians, and occasionally in Czechia (Pawłowski et al. 1960; Hájek 1999; Hájek and Hájková 2002, 2011; Hájek et al. 2002). In Poland, Koczur and Nicia (2013) reported a substantial variability in the assemblage, mainly produced by the wide range of the habitat parameters, notably the soil $\mathrm{pH}$, varying from (5.8-)6 to (7.6-)8 (see also Mazurek and Nicia 2006); our study, however, showed the Valeriano simplicifoliae-Caricetum flavae to be a rather homogenous fen community (see also Hájek 1999), despite the habitat varying 
Table 5 Results of Kruskal-Wallis test and post hoc Dunn's multiple comparisons test, showing significance of differences in soil properties at Carex flava agg. Sites sampled. F-C. flava s.str.;
$\mathrm{D}-C$. demissa $; \mathrm{L}-C$. lepidocarpa $; \mathrm{V}-C$. viridula; the significance level of $P \leq 0.05$ is marked with bold. For abbreviations of soil properties, see Table 3 .

\begin{tabular}{|c|c|c|c|c|c|c|c|c|}
\hline \multirow[t]{2}{*}{ Soil properties } & \multicolumn{2}{|c|}{ Kruskal-Wallis test } & \multicolumn{6}{|c|}{ Dunn's multiple comparisons test } \\
\hline & $H$ & $P$ & $\begin{array}{l}\mathrm{F}-\mathrm{L} \\
P\end{array}$ & $\begin{array}{l}\mathrm{F}-\mathrm{V} \\
P\end{array}$ & $\begin{array}{l}\text { F-D } \\
P\end{array}$ & $\begin{array}{l}\mathrm{L}-\mathrm{V} \\
P\end{array}$ & $\begin{array}{l}\mathrm{L}-\mathrm{D} \\
P\end{array}$ & $\begin{array}{l}\text { V-D } \\
\text { P }\end{array}$ \\
\hline $\mathrm{C}[\%]$ & 34.16 & 0.000 & 0.105 & 0.000 & 0.366 & 0.000 & 0.000 & 1.000 \\
\hline $\mathrm{N}[\%]$ & 34.30 & 0.000 & 1.000 & 0.000 & 0.108 & 0.000 & 0.079 & 0.026 \\
\hline $\mathrm{C} / \mathrm{N}$ & 17.72 & 0.000 & 0.003 & 1.000 & 0.013 & 0.117 & 1.000 & 0.272 \\
\hline $\mathrm{Ca}[\mathrm{mg} / \mathrm{kg}]$ & 38.77 & 0.000 & 0.005 & 0.003 & 0.101 & 0.000 & 0.000 & 1.000 \\
\hline $\mathrm{Mg}[\mathrm{mg} / \mathrm{kg}]$ & 34.25 & 0.000 & 0.002 & 0.012 & 1.000 & 0.000 & 0.001 & 1.000 \\
\hline $\mathrm{CaCO}_{3}[\%]$ & 27.12 & 0.000 & 0.005 & 1.000 & 1.000 & 0.027 & 0.004 & 0.443 \\
\hline $\mathrm{P}[\mathrm{mg} / \mathrm{kg}]$ & 10.39 & 0.016 & 0.008 & 1.000 & 1.000 & 0.196 & 0.349 & 0.945 \\
\hline $\mathrm{K}[\mathrm{mg} / \mathrm{kg}]$ & 27.07 & 0.000 & 0.006 & 0.000 & 1.000 & 1.000 & 0.236 & 0.034 \\
\hline $\mathrm{pH}$ & 38.33 & 0.000 & 0.000 & 1.000 & 0.006 & 0.002 & 0.000 & 0.00 \\
\hline org. Mat. [\%] & 38.52 & 0.000 & 0.651 & 0.000 & 0.341 & 0.000 & 0.027 & 0.4232 \\
\hline
\end{tabular}

from acidic to slightly alkaline (from 5.0 to 7.6). The assemblage showed a fairly constant floristic composition, but a high number of species from the class Molinio-Arrhenatheretea points to its potential to become transformed into a grasslands community. In Czechia, the Valeriano simplicifoliae-Caricetum flavae is vicariant to the Valeriano dioicaeCaricetum davallianae in the mountainous regions of the Western Carpathians (Hájek and Hájková 2011). In Poland we found patches featuring Carex flava and Valeriana dioica s.str. as well as other species diagnostic for the Valeriano dioicaeCaricetum davallianae, for example Carex panicea, Potentilla erecta, Succisa pratensis, Calliergonella cuspidata (Hájek and Hájková 2011); however, C. davalliana was not found at any of our sites and the proportion of wet grasslands species was considerable. In Poland, V. dioica subsp. simplicifolia and $V$. dioica s.str. are vicariants; the former occurs mainly in the East and South-East whereas the latter is known from the central and western part of the country (Zając and Zając 2001). According to Zarzycki et al. (2002), the taxa are similar in their habitat requirements, but are different in terms of their continentalism and, to a lesser extent, in acidity preference: $V$. dioica subsp. simplicifolia is subcontinental and usually grows on alkaline soils (more seldom on soil with neutral $\mathrm{pH}$ ), whereas $V$. dioica s.str. is a sub-Atlantic species and grows on neutral
$\mathrm{pH}$ soils. Our study confirmed the presence of the Valeriano simplicifoliae-Caricetum flavae in the Bieszczady Mountains, while the remaining patches with C. flava (outside of the Bieszczady) are heterogenous and represent various associations, usually the wet grasslands ones from the class MolinioArrhenatheretea.

Carex demissa usually occurs in poor and moderaterich fens as well as along forest roads and paths. In Poland, it was usually reported from acidic sites $(\mathrm{pH}$ 3.4-5.5) with usually a very low calcium concentration and with a carbonate-poor soil. It was only at a single

Fig. 4 Ranges of soil properties at C. flava agg. sites in Poland. Large boxes indicate $25-75 \%$ of the interquartile ranges; small boxes are medians; circles denote outliers; asterisks mark extreme values. Carex lepidocarpa - cluster I; C. viridula - II, IIIa, IIIb, IV; C. demissa - Va, Vb, C. flava - VI, VII, VIII (the cluster numbers are compatible with Online Resource 2 and 3). The diagrams show statistically significant differences only within C. viridula (between four clusters), C. demissa (between two clusters) and C. flava (between three clusters) sites. The significance of differences between species sites is shown in Table 5. a - Carbon, $P=0.0019, P_{1}=0.0416, P_{2}=0.0013, P_{3}=$ $0.0023, P_{4}=0.0058 ; \mathrm{b}-$ Nitrogen, $P=0.0016, P_{1}=0.0028, P_{2}=$ $0.0005, P_{3}=0.0038 ; \mathrm{c}-$ Organic matter content, $P=0.0262, P_{1}=$ $0.0416, P_{2}=0.0009, P_{3}=0.0029, P_{4}=0.0083 ; \mathrm{d}-\mathrm{pH}$ value, $P=$ 0.0021, $P_{1}=0.0008, P_{2}=0.0050 ; \mathrm{e}-$ Potassium, $P=0.0275, P_{1}=$ $0.0000, P_{2}=0.0232 ; \mathrm{f}-$ Magnesium, $P=0.0426, P_{1}=0.0293, P_{2}$ $=0.0014, P_{3}=0.0009, P_{4}=0.0189 ; \mathrm{g}-$ Calcium, $P=0.0107, P_{1}=$ $0.0027, P_{2}=0.0003, P_{3}=0.0081 ; \mathrm{h}-$ Carbonates, $P=0.0493, P_{1}$ $=0.0055, P_{2}=0.0285$. 

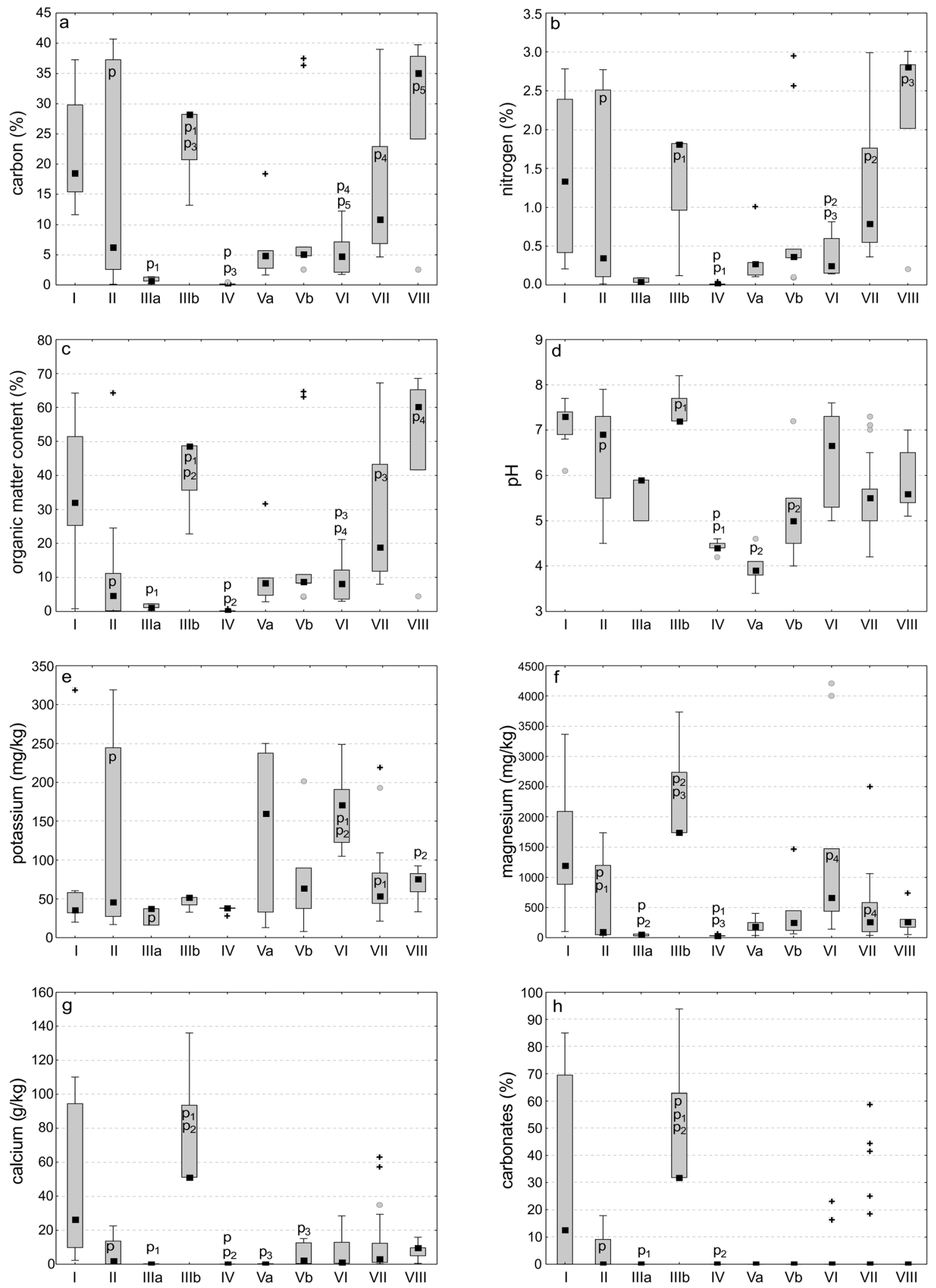
site, the northernmost one, about $700 \mathrm{~m}$ away from the Baltic Sea shore, that $C$. demissa was found growing on soil with a $\mathrm{pH}$ exceeding 7. In Central and Southern Europe, C. demissa is usually found on acidic and slightly acidic soils, for example in Switzerland (Schmid 1984), Bulgaria, Czechia, and Slovakia (Stoeva and Štepánková 1990). In Northern Europe (e.g. in Finland), C. demissa is weakly calciphilous and occurs on nutrient-rich soils. According to Pykälä and Toivonen (1994), this lends support to the known observation of a species strengthening its requirements at the boundary of its range. In Poland, the structure and floristic composition of communities with $C$. demissa as well as the soil parameters, mainly $\mathrm{pH}$, correspond with those typical of the Carici echinatae-Sphagnetum (cluster Va) and Carici canescentis-Agrostietum caninae (cluster Vb), see Hájek and Hájková (2002, 2011), Hájek et al. (2008), and Koczur and Nicia (2013). The habitat of the latter represents one of the most common types of fen grasslands on non-calcareous bedrock in Central Europe (e.g. Dítě et al. 2007; Hájek and Hájková 2011; Matuszkiewicz 2018).

Carex viridula usually grows in open habitats (e.g. wet grasslands, fens, dunes, lake and pond shores) and is capable of colonising variable and unstable sites (Davies 1956; Schmid1984; Stoeva and Štepánková 1990; Więcław 2014a,b, 2017). The sedge has been reported from various plant assemblages, mainly the classes Isoëto-Nanojuncetea, Littorelletea uniflorae and Scheuchzerio palustris-Caricetea fuscae (e.g. Šumberová 2011; Šumberová et al. 2011).

In Poland, C. viridula is regarded as one of the species characteristic of the Cyperetum flavescentis from the class Isoëto-Nanojuncetea, which appears spontaneously on emergent bottom and shores of water reservoirs (Popiela 1997; Matuszkiewicz 2018). However, our study found $C$. viridula to grow, along lake shores, in Ranunculo-Juncetum bulbosi communities from the class Littorelletea uniflorae (see also Szańkowski and Kłosowski 2006; Hrivnák et al. 2011; Šumberová et al. 2011). All the sites with $C$. viridula located along lake shores were supported by the bryophyte Bryum pseudotriquetrum, which is common in wet and moderately infertile sites (Ellenberg et al. 1991). According to Dierßen (2001) this species can also occur on slightly acidic habitats such as fens and lake shores.

Communities featuring C. viridula and occurring in humid dune depressions along the Polish Baltic Sea coast are similar to marsh assemblages of the class Scheuchzerio palustris-Caricetea fuscae. Theurillat et al. (2015) distinguished, within the class Scheuchzerio palustris-Caricetea fuscae, the alliance Caricion viridulo-trinervis, which covers low-sedge vegetation of wet, phosphorus-limited dune slacks of Atlantic coasts of Western Europe (see also Peterka et al. 2017). On the other hand, Sival and Grootjans (1996) frequently recorded C. viridula on dune slacks of the island of Schiermonnikoog in the northern part of the Netherlands in a pioneer assemblage with Littorella uniflora, Samolus valerandi, Radiola linoides and Juncus bulbosus. In Poland, the relevés made in between-dune depressions were distinct in showing the presence of the bryophyte Pohlia nutans, common and often abundant on wet or dry, acidic, peaty, sandy or gravelly soil on heaths and moors, in sand dunes, acidic grassland, bogs, and woods. It avoids base-rich or calcareous sites (Ellenberg et al. 1991).

Carex viridula is fairly frequently found also in fens and wet grasslands across a wide spectrum of soil conditions (e.g. Więcław and Podlasiński 2013), in communities representing both the class Scheuchzerio palustris-Caricetea fuscae and the MolinioArrhenatheretea. According to Hájek et al. (2008), C. viridula reached a high cover in disturbed moderately rich fens in Bulgaria and occurred with some calciphilous species, for example Eriophorum latifolium and Parnassia palustris. In Poland, C. viridula can also grow at sites with a high soil calcium carbonate level (see also Więcław and Podlasiński 2013) and is capable of colonizing heavily disturbed sites (Więcław 2017). Thus, the ecological niche of $C$. viridula is very wide, compared to that of C. flava, C. lepidocarpa and C. demissa. Carex viridula grows in various plant communities without any tight syntaxonomic affinity.

Ecological differentiation within closely related species

In Poland, the Carex flava complex includes four closely related sedge species (Więcław 2014a), which, as shown in this study, occupy diverse habitats and have diverse ecological requirements. In general, many closely related taxa may be distinctly different in their ecological preferences (e.g. Dakskobler et al. 1999; Hölzel 2003; Koutecká et al. 2011; Budzhak et al. 2016). A clear differentiation, both in the community composition, soil properties, and habitat types was revealed within the Bolboschoenus maritimus group (Hroudová 
et al. 1999). According to Hroudová et al. (1999), the closely related taxa of the Bolboschoenus maritimus group show a much stronger ecological than morphological differentiation (no distinct diagnostic characters). Our investigation has shown that $C$. lepidocarpa and $C$. demissa are the most ecologically isolated species of the $C$. flava complex. The former was found on calcareous and extremely rich fens (Caricion davallianae) whereas the latter was reported from poor and moderately rich fens (Sphagno-Caricion canescentis and Caricion canescenti-nigrae). However, earlier morphological studies on the C. flava group in Poland showed $C$. lepidocarpa and $C$. demissa to be fairly distinctly separated morphologically, mainly in the dimensions of the generative characters (Wiecław 2014a). Similarly, taxa within the Festuca varia group were well separated both morphologically and ecologically, syntaxonomic studies on the group showing the presence of five vicariating regional associations and one edaphically determined association, growing on ecologically different sites (Wallossek 1999). Other studies, addressing species of the Molinia caerulea complex in Central Europe (Molinia caerulea s.str. and $M$. arundinacea), showed differences in their morphology and chromosome number (Dančák et al. 2012) as well as in habitat preferences (Budzhak et al. 2016). Comparative studies on three related species of the genus Viola, combined with their phytosociology and environmental parameters showed the species to differ in terms of their association with the soil moisture gradient and chemistry (Hölzel 2003). Koutecká et al. (2011) reported results of phytosociological research which clearly separated three Myosotis species from the Myosotis palustris group into different types of habitats and plant communities. They found only two locations with the simultaneous presence of two Myosotis species (M. caespitosa and M. nemorosa). These examples show closely related species to differ fairly distinctly in terms of micro-species morphology and to be clearly separated by ecological preferences. This pattern is, however, not so pronounced within the C. flava complex.

Our study showed the $C$. flava taxa to be capable of sharing a habitat, except for $C$. lepidocarpa and C. demissa, distinctly separated ecologically in Poland. Carex lepidocarpa and C. flava s.str. Can co-occur on calcareous and rich fens (Caricion davallianae). They are clearly different morphologically (e.g. Schmid 1984; Crins and Ball 1989a,b; Pykälä and Toivonen 1994;
Więcław 2014a), but mixed populations frequently support hybrids, whereby an unequivocal species identification is challenging (Więcław and Wilhelm 2014). The ecological amplitude of Carex flava s.str. is wider than that of $C$. lepidocarapa; the former species can also grow on wet grasslands and moderate-rich fens, where frequently co-occurs with $C$. demissa and their hybrid (C. ×alsatica). Carex flava s.str. and C. demissa are rather well separated morphologically, but the problem of intermediate hybrids present in their mixed populations appears here as well (Więcław and Wilhelm 2014).

Carex viridula is encountered both in calcareous, extremely and moderately rich fens, wet grasslands, and in very poor habitats such as dunes and sandy lake shores. Carex viridula frequently co-occurs with both C. lepidocarpa and C. flava, and much more seldom with $C$. demissa (Więclaw 2014a,b) and hybridizes with all three mentioned species (Więcław and Wilhelm 2014; Schmidt et al. 2018). Carex viridula is morphologically different from both C. flava and C. lepidocarpa, mainly in its much smaller utricles and shorter beaks, but is morphologically very close to C. demissa (e.g. Pykälä and Toivonen 1994; Hedrén 2003; Więcław 2014a). Noteworthy is the fact that Carex viridula is the only species of the C. flava complex which grows on sandy lake shores and in dune depressions.

To sum up, detailed knowledge on closely related species, combining results of taxonomic and environmental studies, allows us to fairly precisely determine the ecological amplitude of narrowly-defined species. The combination of an ecological and taxonomic approach may lead to a better understanding of the evolutionary ecology of plants.

\section{Compliance with ethical standards}

Conflict of interest The authors declare that they have no conflict of interest.

Open Access This article is licensed under a Creative Commons Attribution 4.0 International License, which permits use, sharing, adaptation, distribution and reproduction in any medium or format, as long as you give appropriate credit to the original author(s) and the source, provide a link to the Creative Commons licence, and indicate if changes were made. The images or other third party material in this article are included in the article's Creative Commons licence, unless indicated otherwise in a credit line to the material. If material is not included in the article's Creative Commons licence and your intended use is not permitted by statutory 
regulation or exceeds the permitted use, you will need to obtain permission directly from the copyright holder. To view a copy of this licence, visit http://creativecommons.org/licenses/by/4.0/.

\section{References}

Budzhak VV, Chorney II, Tokariuk AI, Kuzemko AA (2016) Numeric syntaxonomical analysis of communities of the Molinia caerulea complex in Southwestern of Ukraine. Hacquetia 15:63-77

Chater AO (1980) Carex L. In Tutin TG, Heywood VH, Burges NA, Moore DM, Walters SM, Webb DA (eds) Flora Europaea 5 (Alismataceae to Orchidaceae). Cambridge University Press, Cambridge, pp. 290-323

Crins W J, Ball PW (1989a) Taxonomy of the Carex flava complex (Cyperaceae) in North America and northern Eurasia. I. Numerical taxonomy and character analysis. Canad J Bot 67: 1032-1047

Crins WJ, Ball PW (1989b) Taxonomy of the Carex flava complex (Cyperaceae) in North America and northern Eurasia. II. Taxonomic treatment. Canad J Bot 67:1048-1065

Dančák M, Duchoslav M, Trávníček B (2012) Taxonomy and cytogeography of the Molinia caerulea complex in central Europe. Preslia 84:351-374

Dakskobler I, Seliškar A, Vreš B (1999) Stellaria nemorum L. and S. montana Pierrat (Caryophyllaceae) in the forest communities of Slovenia. Folia Geobot 34:115-125

Davies EW (1956) The ecology and distribution of Carex flava and its allies in the British Isles. Bot Not 109:51-74

Dierßen K (2001) Distribution, ecological amplitude and phytosociological characterization of European bryophytes. Bryophyt Biblioth 56:1-289

Dítě D, Hájek M, Hájková P (2007) Formal definitions of Slovakian mire plant associations and their application in regional research. Biologia 62:400-408

Ellenberg H, Weber HE, Düll R, Wirth V, Werner W, Paulißen D (1991) Zeigerwerte von Pflanzen in Mitteleu-ropa. Scripta Geobot 18:1-248

Grootjans A, Bulte M, Wołejko L, Pakalne M, Dullo B, Eck N, Fritz Ch (2015) Prospects of damaged calcareous spring systems in temperate Europe: Can we restore travertinemarl deposition? Folia Geobot 50:1-11

Hájek M (1999) The Valeriano simplicifoliae-Caricetum flavae association in the Podhale Region (Western Carpathians, Poland): notes on syntaxonomical and successional relationships. Fragm Florist Geobot 44:389-400

Hájek M (2002) The class Scheuchzerio-Caricetea fuscae in the Western Carpathians: indirect gradient analysis, species groups and their relation to phytosociological classification. Biologia 57:461-469

Hájek M, Hájková P (2002) Vegetation composition, main gradient and subatlantic elements in spring fens of the northwestern Carpathian borders. Thaiszia 12:1-24

Hájek M, Hájková P (2011) Vegetace slatiništ', přechodových rašeliništ' a vrchovištních šlenků (Vegetation of fens, transitional mires and bog hollowi) In Chytrý M (ed) Vegetace
České republiky. Vodni a mokřadni vegetace (Vegetation of the Czech Republic. Aquatic and Wetland Vegetation) 3. Academia, Praha, pp 614-701

Hájek M, Hájková P, Apostolova I (2008) New plant associations from Bulgarian mires. Phytol Balcan 14 :377-399

Hájek M, Hájková P, Rybníček K, Hekera P (2005) Present vegetation of spring fens and its relation to water chemistry. In Poulíčková A, Hájek M. Rybníček K (eds) Ecology and palaeoecology of spring fens of the West Carpathians 5. Palacký University Press Olomouc, Academy of Sciences of the Czech Republic, Masaryk University Brno, pp 69-95

Hájek M, Hekera P, Hájková P (2002) Spring fen vegetation and water chemistry in the Western Carpathian flysch zone. Folia Geobot 37:205-224

Hájek M, Horsák M, Hájková P, Dítě D (2006) Habitat diversity of Central European fens in relation to environmental gradients and an effort to standardise fen terminology in ecological studies. Perspect Pl Ecol Evol Syst 8:97-114

Hájková P, Hájek M, Blažková D, Kučera T, Chytrý M, Řezníčková M et al (2010) Louky a mezofilní pastviny (Meadows and mesic pastures) In Chytrý M (ed) Vegetace České republiky. Travinná a keřičková vegetace (Vegetation of the Czech Republic. Grassland and heathland vegetation) 1. Academia, Praha, pp 165-280

Havlíčková J (1982) Carex flava-complex in the Czech lands. I. Analysis of the variability of morphological characters. Preslia 54:201-222

Hedrén M (2003) Patterns of allozyme and morphological differentiation in the Carex flava complex (Cyperaceae) in Fennoscandia. Nordic J Bot 22:257-301

Hill MO, Šmilauer P (2005) Twinspan for Windows version 2.3. Centre for Ecology and Hydrology, University of South Bohemia, Huntingdon \& České Budějovice

Hölzel N (2003) Re-assessing the ecology of rare flood-meadow violets (Viola elatior, V. pumila, V. persicifolia) with large phytosociological data sets. Folia Geobot 38: 281-298

Hrivnák R, Kochjarová J, Ot’ahel’ová H (2011) Vegetation of the aquatic and marshland habitats in the Orava region, including the first records of Potametum alpini, Potametum zizii and Ranunculo-Juncetum bulbosi in the territory of Slovakia. Biologia 66:626-637

Hroudová Z, Zákravský P, Frantík T (1999) Ecological differentiation of central European Bolboschoenus taxa and their relationship to plant communities. Folia Geobot 34:77-96

Jarolímek I, Šibík J (eds) (2008) Diagnostic, constant and dominant species of the higher vegetation units of Slovakia. Veda, Bratislava

Jiménez-Mejías P, Martín-Bravo S, Luceño M (2012) Systematics and taxonomy of Carex sect. Ceratocystis (Cyperaceae) in Europe: a molecular and cytogenetic approach. Syst Bot 37: 382-398

Koczur A, Nicia P (2013) Spring fen Scheuchzerio-Caricetea nigrae in the Polish Western Carpathians - vegetation diversity in relation to soil and feeding waters. Acta Soc Bot Poloniae 82:117-124

Koopman J (2015) Carex Europaea. The genus Carex L. (Cyperaceae) in Europe 1. Accepted names, hybrids, 
synonyms, distribution, chromosome numbers. Ed. 2 (2nd reprint), Margraf Publishers, Weikersheim

Koutecká E, Koutecký P, Lepš J (2011) Comparison of community composition and site conditions between three closely related Myosotis species IV. In Koutecká E (ed) Ecological comparison of three closely related species from Myosotis palustris group. $\mathrm{PhD}$. Thesis [in English/Czech], University of South Bohemia, Faculty of Science. České Budějovice, Czech Republic, pp 117-135

Kovach WL MVSP PLUS version 3.1. Pentraeth (1985-1999)

Kwiatkowski P (1999) Caricetum paniceo-lepidocarpae - a plant association new to Poland. Fragm Florist Geobot 44:375388

Matuszkiewicz W (2018) Przewodnik do oznaczania zbiorowisk roślinnych Polski (Guide to the determination of plant communities in Poland). Ed. 3 (3rd reprint), Wydawnictwo Naukowe PWN, Warszawa

Mazurek R, Nicia P (2006) Micromorphological properties of low sedge mountain fen soils. Polish J Environm Stud 15:80-85

Mucina L, Bültmann H, Dierßen K, Theurillat J-P, Raus T, Čarni A et al (2016) Vegetation of Europe: hierarchical floristic classification system of vascular plant, be, lichen, and algal communities. Applied Vegetation Science 19(Suppl. 1):3264

Ochyra R, Żarnowiec J, Bednarek-Ochyra H (2003) Census catalogue of Polish mosses. Institute of Botany, Polish Academy of Sciences, Cracow

Pawłowski B, Pawłowska S, Zarzycki K (1960) Zespoły roślinne kośnych tak pótnocnej cześci Tatr i Podtatrza (Les associations végétales des praires fauchables de la partie septentrionale des Tatras et de la Region subtatrique) Fragm Florist Geobot 6:95-227

Peterka T, Hájek M, Jiroušek M, Jiménez-Alfaro B, Aunina L, Bergamini A et al (2017) Formalized classification of European fen vegetation at the alliance level. Appl Veg Sci 20:124-142

Popiela A (1997) Zbiorowiska namułkowe z klasy IsoëtoNanojuncetea Br.-Bl. et Tx. 1943 w Polsce (Occurrence of the Isoëto-Nanojuncetea Br.-B1. et Tx. 1943 class communities in Poland) Monogr Bot 80:1-59

Pykälä J (1994) The ecology and distribution of Carex lepidocarpa subsp. lepidocarpa in Finland. Ann Bot Fenn 31:261-274

Pykälä J, Toivonen H (1994) Taxonomy of the Carex flava complex (Cyperaceae) in Finland. Nordic J Bot 14:173-191

Schmid B (1982) Karyology and hybridization in the Carex flava complex in Switzerland. Feddes Repert 93:23-59

Schmid B (1984) Niche width and variation within and between populations in colonizing species (Carex flava group). Oecologia 63:1-5

Schmidt L, Fischer M, Oja T (2018) Two closely related species differ in their regional genetic differentiation despite admixing. AoB PLANTS 10:ply007

Sival FP, Grootjans AP (1996) Dynamics of seasonal bicarbonate supply in a dune slack: effects on organic matter, nitrogen pool and vegetation succession. Vegetatio 126:39-50

Sparks DL, Page AL, Helmke PA, Loeppert RH (1996) Methods of soil analysis part 3 - chemical methods. SSSA Book Ser.
5.3. Soil Science Society of America, American Society of Agronomy, Madison.

StatSoft, Inc. (2013) Electronic Statistics Textbook. Tulsa, OK: StatSoft. Available at http://www.statsoft.com/textbook

Stoeva MP, Štepánková J (1990) Variation patterns within the Carex flava agg. in Bulgaria and Czechoslovakia. Preslia 62:1-24

Šefferová Stanová V, Šeffer J, Janák M (2008) Management of Natura 2000 habitats. 7230 Alkaline fens. Technical Report 200820/24 Directive 92/43/EEC on the conservation of natural habitats and of wild fauna and flora DAPHNE. Institute of Applied Ecology, Slovakia

Šumberová K (2011) Vegetace jednoletých vlhkomilných bylin (Vegetation of annual wetland herbs) In Chytrý M (ed) Vegetace České republiky. Vodni a mokřadni vegetace (Vegetation of the Czech Republic Aquatic and Wetland Vegetation) 3. Academia, Praha, pp 309-338

Šumberová K, Hrivnak R (2013) Formalised classification of the annual herb vegetation of wetlands (Isoëto-Nano-Juncetea class) in the Czech Republic and Slovakia (Central Europe). Phytocoenologia 43:13-40

Šumberová K, Navrátilová J, Čtvrtlíková M, Hájek M, Bauer P (2011) Vegetace oligotrofních vod (Vegetation of oligotrophic water bodies) In Chytrý M (ed) Vegetace České republiky. Vodni a mokradni vegetace (Vegetation of the Czech Republic. Aquatic and Wetland Vegetation) 3. Academia, Praha, pp 268-309

Szańkowski M, Kłosowski S (2006) Habitat variability of the Littorelletea uniflorae plant communities in Polish Lobelia lakes. Hydrobiologia 570:117-126

Tatzber M, Stemmer M, Spiegel H, Katzlberger C, Haberhauer G, Gerzabek M (2007) An alternative method to measure carbonate in soils by FT-IR spectroscopy. Environm Chem Lett 5:9-12

ter Braak CJF, Šmilauer P (2002) CANOCO Reference Manual and User's Guide to Canoco for Windows: Software for Canonical Community Ordinantion (version 4.5) Microcomputer Power. Ithaca, NY, USA.

Theurillat J-P, Mucina L, Hájek M (2015) Validations of highrank syntaxa in Potamogetonetea and ScheuchzerioCaricetea fuscae. Lazaroa 36:67-73

van der Maarel E (1979) Transformation of cover-abundance values in phytosociology and its effect on community similarity. Vegetatio 39:97-114

Vončina G (2017) Młaki eutroficzne polskich Karpat [Eutrophic fens in the Polish Carpathians]. The Committee of Organismal Biology of Polish Academy of Sciences Insitute of Biology of Jagiellonian University. Warszawa Kraków

Wallossek C (1999) The acidophilous taxa of the Festuca varia group in the Alps: new studies on taxonomy and phytosociology. Folia Geob Phytotax 34:47-75

WFO (2020) World Flora Online. Published on the Internet; Available http://www.worldfloraonline.org. (Accessed on 23 Mar 2020)

Więcław H (2014a) Carex flava aggregate (section Ceratocystis, Cyperaceae) in Poland: taxonomy, morphological variation, and soil conditions. Biodivers Res Conservation 33:3-47 
Więcław H (2014b) Carex flava aggregate (section Ceratocystis, Cyperaceae) in Poland: distribution maps and locality lists. Biodivers Res Conservation 33:49-84

Więcław H (2017) Within-species variation among populations of the Carex flava complex as a function of habitat conditions. Pl Ecol Diversity 10:443-451

Więcław H, Koopman J (2013) Numerical analysis of morphology of natural hybrids between Carex hostiana DC. and the members of Carex flava agg. (Cyperaceae). Nordic J Bot 31:464-472

Więcław H, Podlasiński M (2013) Morphological differences between natural populations of Carex viridula (Cyperaceae): effects of soil conditions. Ann Bot Fenn 50: $13-22$

Więcław H, Wilhelm M (2014) Natural hybridization within the Carex flava complex (Cyperaceae) in Poland: morphometric studies. Ann Bot Fenn 51:129-147

Wołejko L, Herbichowa M, Potocka J (2005) Typological differentiation and status of Natura 2000 mire habitats in Poland.
Stapfia 85, zugleich Kataloge der OÖ. Landesmuseen Neue Serie 35:175-219

Zając A (1968) Carex serotina Mér. subsp. pulchella (Lönnr.) v. Ooststr., w Polsce. Fragm Florist Geobot 14:205-211

Zając A, Zając M (eds) (2001) Distribution Atlas of Vascular Plants in Poland. Laboratory of Comuter Chorology, Institute of Botany, Jagiellonian University, Kraków, pp. 714

Zamfirescu O, Zamfirescu ŞtR (2006) Diversity analysis of plant communities with Carex flava from the Ceahlău mountain. Contr Bot 41:61-66

Zarzycki K, Trzcińska-Tacik H, Różański W, Wołek J, Korzeniak U (2002) Ecological indicator values of vascular plants of Poland. In Mirek Z (ed) Biodiversity of Poland. 2, W. Szafer Institute of Botany, Polish Academy of Sciences, Kraków, pp. 183

Publisher's Note Springer Nature remains neutral with regard to jurisdictional claims in published maps and institutional affiliations. 